\title{
Antioxidant and antibacterial activity of extracts, fractions and isolated substances from the flowers of Acacia podalyriifolia A. Cunn. ex G. Don
}

\author{
Cláudia Alexandra de Andrade ${ }^{1, *}$, João Luiz de Souza Carvalho', Miriam Machado Cunico ${ }^{1}$, \\ Ana Luísa Lacava Lordello ${ }^{2}$, Carmen Etsuko Kataoka Higaskino ${ }^{3}$, Siumara Costa da Cruz \\ Almeida $^{3}$, Josiane de Fátima Gaspari Dias ${ }^{1}$, Vitor Alberto Kerber ${ }^{1}$, Marilis Dallarmi Miguel ${ }^{1}$, \\ Obdúlio Gomes Miguel ${ }^{1, *}$
}

\begin{abstract}
${ }^{1}$ Department of Pharmacy, Federal University of Paraná, ${ }^{2}$ Department of Chemistry, Federal University of Paraná, ${ }^{3}$ Institute of Technology of Paraná
\end{abstract}

\begin{abstract}
The extracts and fractions from the flowers of $A$. podalyriifolia were analyzed previously for antibacterial activity using diffusion in disk, Antioxidant properties were evaluated by determining radical scavenging power (DPPH test) and total phenol content was measured (Folin method). The present study describes the in vitro antibacterial (determining minimum inhibitory concentration) and antioxidant activities (by thiobarbituric acid reactive species - TBARS method) for the ethanol extract, dichloromethane and ethyl acetate fractions and two flavanones (naringenin and 5- $\beta$-D-glycosyl-naringenin) isolated from the flowers of Acacia podalyriifolia A. Cunn. ex G. Don. The flavanones naringenin and 5- $\beta$-D-glycosylnaringenin had not previously been obtained from this species. The most effective antibacterial activity was observed in the ethyl acetate fraction ( $\mathrm{MIC}=0.25 \mathrm{mg} \mathrm{mL}^{-1}$ against Staphylococcus aureus ATCC 6538, $\mathrm{MIC}=0.125 \mathrm{mg} \mathrm{mL}^{-1}$ against Staphylococcus epidermidis ATCC $12229, \mathrm{MIC}=0.5 \mathrm{mg} \mathrm{mL}^{-1}$ against Streptococcus pyogenes ATCC 19615, Klebsiella pneumoniae ATCC 13883 and Proteus mirabilis ATCC 43071). The evaluated samples showed antioxidant activity on the TBARS test, especially for ethanol extract $(1000 \mathrm{ppm})$, which was the most active $(29.43 \% \pm 0.65)$ followed by ethyl acetate fraction (1000 ppm, 24.84\% $\pm 1,28)$, both demonstrating higher activity than that presented by ascorbic acid (1000 ppm, 21.73\% \pm 1.77 ), although lower than the BHT (1000 ppm 35.15\% \pm 3.42 ), both reference compounds. Naringenin and 5- $\beta$-D-glycosyl-naringenin demonstrated antioxidant action, but only naringenin inhibited the growth of gram-positive and gram-negative bacteria.
\end{abstract}

Uniterms: Acacia podalyriifolia/qualitative analysis. Acacia podalyriifolia/phytochemistry. Acacia podalyriifolia/antibacterial activity. Acacia podalyriifolia/antioxidant properties. Flavanones. 5- $\beta$-Dglycosyl-naringenin. Naringenin.

Os extratos e frações de Acacia podalyriifolia foram analisados previamente para a atividade antibacteriana através da difusão em disco e as propriedades antioxidantes foram verificadas pela determinação da capacidade removedora do radical livre DPPH e pela mensuração do conteúdo de fenólicos totais (Método de Folin). O presente estudo descreve as atividades antibacteriana (determinação da concentração inibitória mínima) e antioxidante (espécies reativas do ácido tiobarbitúrico - teste TBARS) para o extrato etanólico e as frações diclorometano e acetato de etila e para duas flavanonas (naringenina e 5- $\beta$-D-glicosilnaringenina) isoladas das flores de Acacia podalyriifolia A. Cunn. ex G. Don. As flavanonas naringenina e 5- $\beta$-D-glicosil-naringenina ainda não haviam sido obtidas desta espécie. A atividade antibacteriana mais efetiva foi observada com a fração acetato de etila (CIM=0,25 mg/mL contra Staphylococcus aureus ATCC 6538; CIM=0,125 mg/mL, contra Staphylococcus epidermidis ATCC 12229; CIM=0,5 mg/mL contra Streptococcus pyogenes ATCC 19615, Klebsiella pneumoniae ATCC 13883 e Proteus mirabilis ATCC 43071). As amostras avaliadas demonstraram atividade pelo teste TBARS, especialmente o extrato

\footnotetext{
"Correspondence: O. G. Miguel. Departamento de Farmácia, Universidade Federal do Paraná. Av. Lothário Meissner, 3400 - 80210-170 - Curitiba - PR, Brazil. E-mail: obdulio@ufpr.br
} 
etanólico (1000 ppm), que foi o mais ativo $(29,43 \% \pm 0.65)$, seguido pela fração acetato de etila (1000 ppm, $24,84 \% \pm 1,28)$, ambos demonstrando atividade mais elevada que a apresentada pelo ácido ascórbico (1000 ppm, $21,73 \% \pm 1,77)$, ainda que menor que a do BHT (1000 ppm, 35,15\% $\pm 3,42)$, ambas substâncias de referência. Naringenina e 5- $\beta$-D-glicosil-naringenina demonstraram ação antioxidante, porém somente a naringenina inibiu o crescimento de bactérias gram-positivas e gram-negativas.

Unitermos: Acacia podalyriifolia/análise qualitativa. Acacia podalyriifolia/atividade antibacteriana. Acacia podalyriifolia/propiedades antioxidantes. Flavanonas. 5- $\beta$-D-Glicosil-naringenina. Naringenina.

\section{INTRODUCTION}

Acacia podalyriifolia A. Cunn. Ex G. Don, Leguminosae-Mimosoideae, is an exotic plant cultivated in the south of Brazil as an ornamental tree (Burkart, 1979). Several species in the gender Acacia present important medicinal applications (Hagos, Samuelsson, 1988; Chhabra et al., 1990; Nabi et al., 1992; Sekine et al., 1997; Kambizi, Afolayan, 2001; Saleem et al., 2001; Andrade et al., 2003; Meera et al., 2005; Wu et al., 2005) and possess phenolic compounds, for which countless biological activities are described (Kerber, Silva, 1993; Andrade et al., 2003; Meera et al., 2005). However, to date, studies of A.podalyriifolia are scarce (White, 1943; Ballandrin et al., 1978; Anderson, Bell, 1976; Churms et al.,1970; Andrade et al., 2003; Andrade et al., 2005; Andrade et al., 2007), motivating research on this species.

The extracts and fractions from A. podalyriifolia were analyzed previously for antibacterial and antioxidant actions and have demonstrated activities. For the evaluation of the antibacterial action, a selection was made against two gram-positive and two gram-negative bacteria, using the diffusion in disk (Andrade et al, 2005). The antioxidant action was verified with the free radical 2,2-diphenyl-1-picrylhydrazyl (DPPH) (Andrade et al., 2007).

Previous results from this study have shown that determination of the minimum inhibitory concentration (MIC), adapted from Brasileiro et al. (2006) with modifications, allows quantitative estimation of the antibacterial activity. For this test, several sequential dilutions of the samples with antibacterial activity were incorporated into the medium, added to the bacterium and incubated for 24 hours. MIC is the lowest concentration of antibacterial agent that is capable of inhibiting the growth of the microorganism in vitro (Brasileiro et al., 2006).

Lipid peroxidation, which occurs by increased oxidative stress caused by reactive oxygen species (ROS), is a known mechanism of cellular damage that contributes to aging and many pathological processes such as chronic inflammation, respiratory disorders, neurodegenerative diseases, diabetes mellitus, atherosclerosis, autoimmu- ne diseases of the endocrine glands and carcinogenesis (Dawn-Linsley et al., 2005; Chanwitheesuk et al., 2005; Andrade et al., 2007).

Antioxidants are substances that can significantly delay or prevent the oxidation of substrates as well as prevent or repair damage caused to cells by reactive oxygen species (Chanwitheesuk et al., 2005).

TBARS assays measure the end-point oxidative damage, being useful to evaluate the effects of induced oxidative stress and protection from lipid peroxidation by antioxidants which may be present in the analyzed material (Dawn-Linsley et al., 2005).

\section{MATERIAL AND METHODS}

Flowers of A. podalyriifolia were collected in Curitiba - Brazil, from June to September, 2007. The material was identified by the botanist Gert Hatschbach of the $\mathrm{Mu}-$ nicipal Botanical Museum of Curitiba and the exsiccate deposited under the number 268.219.

After drying in the shade, $300 \mathrm{~g}$ of flowers of $A$. podalyriifolia were submitted to ethanol extraction, following by liquid-liquid partition with hexane, dichloromethane and ethyl acetate, using Sohxlet, as per methodology described in previous studies (Andrade et al., 2005; Andrade et al., 2007; Carvalho et al., 2009). After the evaporation of the solvents under reduced pressure and temperature of $40^{\circ} \mathrm{C}$, a $0.7 \mathrm{~g}$ of dichloromethane fraction and $6.3 \mathrm{~g}$ of ethyl acetate fraction were obtained.

The dichloromethane fraction $(0.5 \mathrm{~g})$ was submitted to chromatography in a column of silicagel $60(0.063$ to $0.200 \mathrm{~mm})$ Merck ${ }^{\circledR}$ with a mixture of solvents, beginning with hexane, followed by gradually increasing polarity (hexane:ethyl acetate and ethyl acetate:methanol). The crystallization obtained among the sub-fractions 19 to $57(142.2 \mathrm{mg})$ and subsequent analysis by thin-layer chromatography (Aluminum Sheet F254 - Merck ${ }^{\circledR}$ ) with mobile phase chloroform:methanol (90:10), demonstrated a mixture of compounds that were gathered and submitted to chromatographic separation in a column of silicagel 60 ( 0.063 to $0.200 \mathrm{~mm})$ Merck ${ }^{\circledR}$ with the same sequence of previous solvents. Crystals in yellow needles $(15.2 \mathrm{mg})$, 
were obtained corresponding to the group of sub-fractions 2 to 4 , designated as substance 1 .

Also, the ethyl acetate fraction (5 g) was submitted to chromatographic separation in a column of silicagel 60 $(0.063$ to $0.200 \mathrm{~mm})$ Merck ${ }^{\circledR}$ with a mixture of solvents, beginning with ethyl acetate $100 \%$, followed by gradually increasing polarity (ethyl acetate:formic acid and ethyl acetate:methanol:water:formic acid), yielding crystals in white needles $(482 \mathrm{mg})$, corresponding to the group of sub-fractions 20-33, designated as substance 2.

Substances 1 and 2 were exposed to ultraviolet (200$400 \mathrm{~nm}$ ) using the reagents diagnoses, according to Mabry et al. (1970), ${ }^{1} \mathrm{H}$ RMN (300 MHz CD CDCl $\left.{ }_{3}\right),{ }^{13} \mathrm{C} \mathrm{NMR}$ $\left(300 \mathrm{MHz} \mathrm{CDCl}_{3}\right)$ and Infrared $\left(400-4000 \mathrm{~cm}^{-1}\right)$. Substance 2 hydrolized with trifluoroacetic acid 4N (TFA), following thin-layer chromatography (Aluminum Sheet F254 - Merck $\left.{ }^{\circledR}\right)$ with mobile phase isopropanol:ethyl acetate: nitroethane:water (30:5:5:5), and the standard monosaccharides (glucose, galactose, rhamnose, mannose, xylose) and naringenin, using orcinol $1 \%$ in methanol: $\mathrm{H}_{2} \mathrm{SO}_{4}$ (90:10), with heating as disclosed. For substance 1, thinlayer chromatography was performed with authentic sample of naringenin and chloroform: methanol (90:10) as mobile phase.

Naringenin (1): crystals in yellow needles, 3.04\% of production in relation to the dichloromethane fraction $(0.0071 \%$ in relation to the initial material); M.P. $250-252{ }^{\circ} \mathrm{C}$, HRMS (CIMS) $m / z: 294.5[\mathrm{M}+\mathrm{Na}]^{+}$ (272.068 made calculations for $\mathrm{C}_{15} \mathrm{H}_{12} \mathrm{O}_{5}$ ); IR ( $\mathrm{KBr}$ ) 3035-3280 (O-H), 2831-2976 (C-H), 1639 (C=O), 1602 $(\mathrm{C}=\mathrm{C}), 1313-1520(\mathrm{C}-\mathrm{OH}), \mathrm{UV} \lambda_{\max }(\mathrm{MeOH}) 288(3.92)$, 320 (sh) (3.58), (NaOMe) 244 (4.00), 322 (4.18), (NaOAc) 251 (3.43), 320 (4.05), ( $\left.\mathrm{NaOAc} / \mathrm{H}_{3} \mathrm{BO}_{3}\right) 291$ (4.06), 320 (3.27), $\left(\mathrm{AlCl}_{3}\right) 310$ (4.04), 363 (3.20), ( $\left.\mathrm{AlCl}_{3} / \mathrm{HCl}\right) 311$ (4.11), $371(3.41) \mathrm{nm}(\log \varepsilon) ;{ }^{1} \mathrm{H} \mathrm{NMR}\left(300 \mathrm{MHz} \mathrm{CD}_{3} \mathrm{OD}\right)$ $\delta 2.99(1 \mathrm{H}, d d, J 1.8,9.6 \mathrm{~Hz}, \mathrm{H}-3 \alpha), 3.03(1 \mathrm{H}, d d, J 9.6$, $12.6 \mathrm{~Hz}, \mathrm{H}-3 \beta), 5.24(1 \mathrm{H}, d d, J 1.8,9.6 \mathrm{~Hz}, \mathrm{H}-2 \alpha), 5.81$ $(2 \mathrm{H}, s, \mathrm{H}-6,8), 6.74(2 \mathrm{H}, d, J 6.5 \mathrm{~Hz}, \mathrm{H}-3$ ', 5') $7.23(2 \mathrm{H}$, $d, J 6.5 \mathrm{~Hz}, \mathrm{H}-2$ ', 6 '); ${ }^{13} \mathrm{C} \mathrm{NMR}\left(100 \mathrm{MHz} \mathrm{CD}_{3} \mathrm{OD}\right) \delta$ 44.05(C-3), 80.50 (C-2), 96.21 (C-6), 97.09 (C-8), 103.37 (C-10), 116.36 (C-3', C-5'), 129.07 (C-2', C-6'), 131.10 (C-1'), 159.02 (C-4'), 165.47 (C-5), 168.39 (C-7), 164.90 (C-9), 197.81 (C-4).

5- $\beta$-D-glycosyl-naringenin (2): crystals in white needles, $9.64 \%$ of production in relation to the ethyl acetate fraction $\left(0.2 \%\right.$ in relation to the initial; M.P. $172-173{ }^{\circ} \mathrm{C}$; $[\alpha]^{20}{ }_{\mathrm{D}}-121^{\circ}(c \mathrm{c} .3, \mathrm{MeOH})$; HRMS (CIMS) $m / z: 457.1187$ $[\mathrm{M} .+\mathrm{Na}]^{+}\left(434.1213\right.$ made calculation for $\left.\mathrm{C}_{21} \mathrm{H}_{22} \mathrm{O}_{10}\right)$; IR $(\mathrm{KBr}) 3362(\mathrm{O}-\mathrm{H}), 2891-2978(\mathrm{C}-\mathrm{H}), 1685(\mathrm{C}=\mathrm{O}), 1585$ -
$1646(\mathrm{C}=\mathrm{C}), 1458-1531(\mathrm{C}-\mathrm{OH}), \mathrm{UV} \lambda_{\max }(\mathrm{MeOH}): 283$ (4,11), 320 (sh) (3.78), (NaOMe): 249 (4.02), 325 (4.31); (NaOAc): 252 (4.02), 325 (4.31); $\left(\mathrm{NaOAc} / \mathrm{H}_{3} \mathrm{BO}_{3}\right): 283$ (4.15), 321 (sh) (3.88); $\left(\mathrm{AlCl}_{3}\right): 226$ (4.36), 283 (4.15), 320 (sh) (3.83); ( $\left.\mathrm{AlCl}_{3} / \mathrm{HCl}\right): 226$ (4.34), 283 (4.11), 320 (sh) (3.81); nm (log $\varepsilon) ;{ }^{1} \mathrm{H}$ NMR (300 $\left.\mathrm{MHz} \mathrm{CD}_{3} \mathrm{OD}\right) \delta$ $2.56(1 \mathrm{H}, d d, J 2.7,17.10 \mathrm{~Hz}, \mathrm{H}-3 \alpha), 2.99(1 \mathrm{H}, d d, J 12.9$, $17.10 \mathrm{~Hz}, \mathrm{H}-3 \beta$ ), 3.47 a 3.53 (4H of the glucose, $m, \mathrm{H}-2$ '", 3", 4", 5"), $3.71(1 \mathrm{H}, d, J 7.2 \mathrm{~Hz}, \mathrm{H}-6 " \alpha), 3.73(1 \mathrm{H}, d, J$ $7.2 \mathrm{~Hz}, \mathrm{H}-6 ” \beta), 4.67(1 \mathrm{H}, d, J 7.5 \mathrm{~Hz}, \mathrm{H}-1$ '), $5.33(1 \mathrm{H}$, $d d, J 2.7,12.9 \mathrm{~Hz}, \mathrm{H}-2 \alpha), 6.06(1 \mathrm{H}, d, J 2.1 \mathrm{~Hz}, \mathrm{H}-6), 6.37$ $(1 \mathrm{H}, d, J 2.1 \mathrm{~Hz}, \mathrm{H}-8), 6.75(2 \mathrm{H}, d d, J 2.7,8.4 \mathrm{~Hz}, \mathrm{H}-3$ ', $\left.5^{\prime}\right), 7.26\left(2 \mathrm{H}, d d, J 6.0,8.7 \mathrm{~Hz}, \mathrm{H}-2\right.$ ', 6 '); ${ }^{13} \mathrm{C}$ NMR (300 MHz CD 3 OD) $\delta 44.51(\mathrm{C}-3), 60.69$ (C-6"), 69.61 (C-4"), 73.47 (C-2"), 75.57 (C-5"), 77.57 (C-3"), 78.16 (C-2), 97.78 (C-8), 98.96 (C-6), 103.49 (C-1"), 105.38 (C-10), 115.15 (C-3', C-5'), 128.33 (C-2', C-6'), 128.98 (C-1'), 157.69 (C-4'), 160.74 (C-5), 164.24 (C-7), 165.14 (C-9), $190.10(\mathrm{C}-4)$.

Antioxidant activity: The samples obtained from the flowers of Acacia podalyriifolia (ethanol extract, dichloromethane and ethyl acetate fractions and isolated substances naringenin and 5- $\beta$-D-glycosyl-naringenine) were submitted to the antioxidant test thiobarbituric acid reactive species, using concentrations of 100,500 and $1000 \mathrm{ppm}$ (parts per million), according to Morais et al. (2006) with modifications. Ascorbic acid and BHT (butylated hydroxy toluene) were used as reference compounds. The whole procedure was performed in triplicate.

A $0.5 \mathrm{~mL}$ volume of egg yolk solution $(10 \% \mathrm{w} / \mathrm{v})$, and $0.1 \mathrm{~mL}$ of each sample or reference compound was added to test tubes, and the volume completed to $1 \mathrm{~mL}$ with distilled water. Each of the test tubes then received $0.05 \mathrm{~mL}$ of solution of 2,2'-azobis(2-amidinopropane) dihydrochloride - AAPH $(0.07 \mathrm{~mol} / \mathrm{L}), 1.5 \mathrm{~mL}$ of acetic acid $20 \%(\mathrm{pH} 3.5)$ and $1.5 \mathrm{~mL}$ of thiobarbituric acid - TBA $(0.8 \% \mathrm{w} / \mathrm{v})$ in solution of sodium dodecil sulfate - SDS $(1.1 \% \mathrm{w} / \mathrm{v})$. The material thus prepared was subjected to a water bath $\left(95^{\circ} \mathrm{C}\right)$ for 1 hour, while stirring. After cooling, each tube received $5 \mathrm{~mL}$ of $\mathrm{n}$-butanol, centrifuged for 10 minutes at $3000 \mathrm{rpm}$, and the supernatants were measured by spectrophotometer (Shimadzu) at $532 \mathrm{~nm}$. The same process was carried out with control tubes to which all reagents were added except the samples.

The antioxidant activity was determined by the Antioxidant Index (AI) obtained as a percentage, according to the equation: $\mathbf{A I}(\%)=\mathbf{1}-(\mathbf{A} / \mathbf{C}) \times \mathbf{1 0 0}$, where $\boldsymbol{A}$ is the absorbance of the sample and $\boldsymbol{C}$ is the absorbance of fully oxidized control. Results are expressed as mean and standard deviation. The statistical examination of the data 
was performed using the R Project for Statistical Computing (Gnu Operating System, 2010). Mean values were compared by using analysis of the variance (ANOVA) test and differences between means were detected using Tukey's test $(p<0.05)$.

Antibacterial activity: The antibacterial action was ascertained by determination of the minimum inhibitory concentration (MIC), according to Brasileiro et al. (2006) with modifications. The gram - positive strains used were Staphylococcus aureus (ATCC 6538), Staphylococcus epidermidis (ATCC 12229) and Streptococcus pyogenes (ATCC 19615) while the gram-negative strains used were Escherichia coli (ATCC 25922), Klebsiella pneumoniae (ATCC 13883), Proteus mirabilis (ATCC 43071), Pseudomonas aeruginosa (ATCC 27857) and Salmonella typhimurium (ATCC 14028), all acquired by Newprov ${ }^{\circledR}$ in liophylized disk. The bacterial suspensions were adjusted, using a sterile solution of sodium chloride $0.9 \%$, to conform to the turbidity standard 0.5 of the Mac Farland scale $\left(10^{8} \mathrm{CFC} \mathrm{mL}^{-1}\right)$, according to the National Committee For Clinical Laboratory Standards (1997). A $0.1 \mathrm{~mL}$ aliquot of bacterial suspension containing $10^{8} \mathrm{CFC} \mathrm{mL}^{-1}$ was mixed with $100 \mathrm{~mL}$ of sterilized solution of Tween $80(2 \%)$ and this mixture was then used in the assay. A sequential dilution of the samples was used $(2,1,0.5,0.25,0.125$ and $0.075 \mathrm{mg} \mathrm{mL}^{-1}$ ) and added to test tubes containing $1 \mathrm{~mL}$ of the TSB (Tryptic Soybean Broth). Subsequently, $1 \mathrm{~mL}$ of bacterial suspension, previously adjusted, was then applied to each tube. The negative control tube contained only the microorganisms without the samples, while the positive control tube contained the microorganisms and chloramphenicol $\left(2 \mathrm{mg} \mathrm{mL}^{-1}\right)$. The whole process was repeated twice. The material was incubated to $37^{\circ} \mathrm{C}$ for 24 hours. The minimum inhibitory concentration was defined as the lowest concentration where no microbial development occurred, verified by absence of turbidity in the tube containing the sample.

\section{RESULTS AND DISCUSSION}

The dichloromethane fraction submitted to the silicagel column chromatography produced $15.2 \mathrm{mg}$ of crystals in the form of needles that had yellow coloration (substance 1), while the ethyl acetate fraction produced $482 \mathrm{mg}$ of crystals in the form of needles with white coloration (substance 2).

The structures of the isolated substances were determined using classic spectroscopic methods (UV, ${ }^{1} \mathrm{H}$ RMN, ${ }^{13} \mathrm{C}$ RMN, IR and mass spectrometric), analytical thinlayer chromatography with standards and comparisons to the literature (Mabry et al., 1970; Agrawal, 1992; Kerber, Silva, 1993; Saito et al., 1994; Ogundaini et al., 1996; Zapesochnaya et al., 2002; Morimura et al., 2006), which identified substance 1 as naringenin and substance 2 as 5 - $\beta$-D-glycosyl-naringenin (Figure 1).
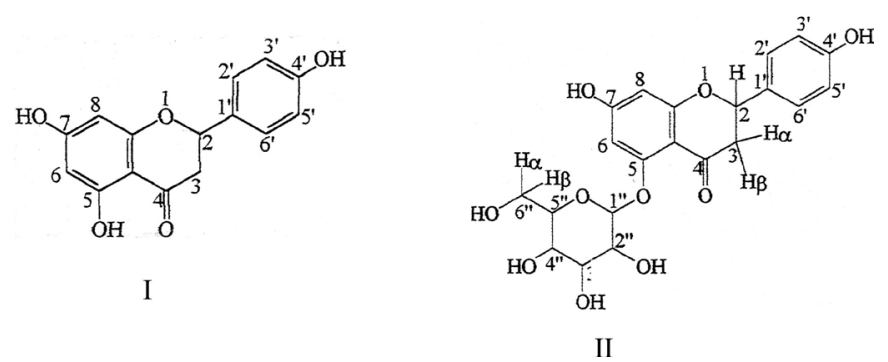

FIGURE 1 - Chemical structure of naringenin (I) and 5- $\beta$-Dglycosyl-naringenin (II).

These compounds had not previously been isolated from Acacia podalyriifolia, but their presence had been noted in the flowers of Acacia longifolia (Kerber, Silva, 1993).

The evaluated samples obtained from the flowers of $A$. podalyriifolia showed antioxidant activity on the TBARS test, especially for ethanol extract (1000 ppm), which was the most active, followed by ethyl acetate fraction $(1000 \mathrm{ppm})$, both demonstrating higher activity than that presented by reference compounds, ascorbic acid (1000 ppm), although were lower than the BHT (1000 ppm). Both isolated substances also showed activity, albeit less intense than those reported by their original fractions (Table I).

For the antibacterial activity, absence of turbidity in the test tubes containing TSB, sample and appraised bacterium, indicates that the sample material at the given concentration, showed an inhibitory effect for the growth of strains. As demonstrated in Table II, the ethanolic extract and the dichloromethane fraction became only slightly active, demonstrating inhibition to the strains of Staphylococcus aureus and Staphylococcus epidermidis with MIC of $1 \mathrm{mg} \mathrm{mL}^{-1}$. The ethyl acetate fraction inhibited the growth of Staphylococcus epidermidis with MIC of $0.125 \mathrm{mg} \mathrm{mL}^{-1}$, Staphylococcus aureus with MIC of $0.25 \mathrm{mg} \mathrm{mL}^{-1}$, Streptococcus pyogenes, Klebsiella pneumoniae and Proteus mirabilis with MIC of $0.5 \mathrm{mg} \mathrm{mL}^{-1}$. For isolated substances, there was inhibitory effect only with naringenin (MIC of $2 \mathrm{mg} \mathrm{mL}^{-1}$ ) to Staphylococcus aureus, Staphylococcus epidermidis, Klebsiella pneumoniae and Proteus mirabilis. 5- $\beta$-D-glycosyl-naringenine caused no inhibitory effect at the given concentrations.

The results obtained on these tests have demonstrated the ethyl acetate fraction was more active. Although the flavanone 5- $\beta$-D-glycosyl-naringenin, the substance 
TABLE I - Antioxidant Index (\%), obtained by TBARS test, of reference compounds and extracts, fractions and isolated substances from the flowers of Acacia podalyriifolia A. Cunn. ex G. Don

\begin{tabular}{lcccccc}
\hline Concentration & \multicolumn{2}{c}{$\mathbf{1 0 0 0} \mathbf{~ p p m}$} & \multicolumn{2}{c}{$\mathbf{5 0 0} \mathbf{~ p p m}$} & \multicolumn{2}{c}{$\mathbf{1 0 0} \mathbf{~ p p m}$} \\
\hline Sample & AI & SD & AI & SD & AI & SD \\
\hline BHT & 35.15 & $3.42 \mathrm{ac}$ & 20.25 & $1.07 \mathrm{bc}$ & 10.73 & $0.59 \mathrm{cab}$ \\
Ascorbic acid & 21.73 & $1.77 \mathrm{af}$ & 14.87 & $1.44 \mathrm{bd}$ & 3.67 & $0.70 \mathrm{cdef}$ \\
Ethanol extract & 29.43 & $0.65 \mathrm{acde}$ & 18.05 & $2.01 \mathrm{bcd}$ & 13.07 & $1.91 \mathrm{ca}$ \\
Ethyl acetate fraction & 24.84 & $1.28 \mathrm{aef}$ & 16.45 & $1.73 \mathrm{bcd}$ & 5.98 & $1.38 \mathrm{ccde}$ \\
Dichloromethane fraction & 19.75 & $2.31 \mathrm{afg}$ & 7.60 & $1.42 \mathrm{bf}$ & 4.55 & $1.60 \mathrm{ccde}$ \\
Naringenin & 14.60 & $2.42 \mathrm{ag}$ & 8.60 & $1.31 \mathrm{bef}$ & 0.00 & $0.00 \mathrm{cf}$ \\
5- $\beta$-D-glycosyl naringenin & 27.74 & $2.50 \mathrm{ade}$ & 14.19 & $2.02 \mathrm{bd}$ & 1.63 & $1.55 \mathrm{cef}$ \\
\hline
\end{tabular}

NOTE: AI = antioxidant index (\%), data presented as mean of three experiments with medium values; SD = standard deviation. Differences between means indicated by the same letters are not statistically significant (Tukey's test, $p<0.05$ ).

TABLE II - Antibacterial activity, by determination of MIC, of extracts, fractions and isolated substances from the flowers of Acacia podalyriifolia A. Cunn. ex G. Don

\begin{tabular}{|c|c|c|c|c|c|c|c|c|}
\hline \multirow{2}{*}{$\begin{array}{l}\text { SAMPLES } \\
\left(\mathrm{mg} \mathrm{mL}^{-1}\right)\end{array}$} & \multicolumn{8}{|c|}{$\mathrm{MIC}\left(\mathrm{mg} \mathrm{mL}^{-1}\right)$} \\
\hline & S. aureus & S. epidermidis & S. pyogenes & E. coli & K. pneumoniae & P. aeruginosa & P. mirabilis & S. typhimurium \\
\hline $\mathrm{EE}$ & 1 & 1 & $>2$ & $>2$ & $>2$ & $>2$ & $>2$ & $>2$ \\
\hline EAF & 0.25 & 0.125 & 0.5 & $>2$ & 0.5 & $>2$ & 0.5 & $>2$ \\
\hline NAR & 2 & 2 & $>2$ & $>2$ & 2 & $>2$ & 2 & $>2$ \\
\hline
\end{tabular}

NOTE: $>2$ = absence of inhibition, EE $=$ ethanolic extract, DCMF $=$ dichloromethane fraction, EAF $=$ ethyl acetate fraction, $\mathrm{NAR}=$ naringenin and NARGLY $=5-\beta-\mathrm{D}$ - glycosyl naringenin, $\mathrm{MIC}=$ minimum inhibitory concentration, the lowest concentration where no microbial development occurs, verified by absence of turbidity in the tube with the sample.

isolated in greatest abundance from this fraction, has demonstrated antioxidant action, it showed no activity against the tested bacteria. It is possible that the presence of flavonoids and phenolic compounds in the ethyl acetate fraction, as demonstrated in the phytochemistry studies carried out by Andrade et al. (2003), or a possible synergism among these, could be responsible for the biological effects observed with these samples.

The amount of flavonoids 5- $\beta$-D-glycosyl-naringenin and naringenin in the flowers of $A$. podalyrifolia (2000 $\mu \mathrm{g} \mathrm{g}^{-1}$ and $71 \mu \mathrm{g} \mathrm{g}^{-1}$, respectively) was considerable. Numerous studies describe the pharmacological properties of these compounds. Among the several applications of these flavanones are an antioxidant effect (Acker, 2000), hepatoprotective (Lee et al., 2004; Salgado et al., 2007), anti-inflammatory (Bodet et al., 2008), antiviral (Paredes et al., 2003; Nahmias et al., 2008), antihypertensive (Saponara et al., 2006) and antimutagenic (Choi et al., 1994; Renugadevi, Prabu, 2009) effects. These studies demonstrate the many potential applications of these compounds, with
A. podalyriifolia an important source of these substances.

Further investigation of the ethyl acetate fraction extracted from the flowers of $A$. podalyriifolia may yield further discoveries.

\section{ACKNOWLEDGEMENTS}

The authors would like to thank Gert Hatschbach of the Municipal Botanical Museum of Curitiba (MBM) for the identification of the species and Sandro R. Dias and Keith Wollis for the collaboration in the translation.

\section{REFERENCES}

ACKER, F.V. Flavonoids can replace $\alpha$-tocopherol as an antioxidant. Febs Lett., v.473, n.2, p.45-148, 2000.

AGRAWAL, P.K. NMR Spectroscopy in the structural elucidation of oligosaccharides and glycosides. Phytochemistry, v.31, n.10, p.3307-3330, 1992. 
ANDERSON, D.M.W.; BELL, P.C. Studies of uronic acid materials: Part 49. Partial structural studies of four Acacia gums exudates of the series Phyllodineae. Phytochemistry, v.15, n.2, p.301-303, 1976.

ANDRADE, C.A.; SILVA, V.C.; PEITZ, C.; MIGUEL, M.D.; MIGUEL, O.G.; KERBER, V. A. Revisão do gênero Acacia - atividades biológicas e presença de fenóis derivados do núcleo flavânico. Visão Acad., v.4, n.1, p.47-56, 2003.

ANDRADE, C.A.; PEITZ, C.; CUNICO, M.; CARVALHO, J.L.S.; ABRAHAO, W.M.; MIGUEL, M.D.; MIGUEL, O.G.; KERBER, V.A. Avaliação da atividade antibacteriana e triagem fitoquímica das flores de Acacia podalyriifolia A. Cunn. ex. G. Don Leguminosae-Mimosoidea. Rev. Bras. Farmacogn., v.15, n.1, p.13-15, 2005.

ANDRADE, C.A.; COSTA, C.K.; BORA, K.; MIGUEL, M.D.; MIGUEL, O.G.; KERBER, V.A. Determinação do conteúdo fenólico e avaliação da atividade antioxidante de Acacia podalyriifolia A. Cunn. ex. G. Don LeguminosaeMimosoidea. Rev. Bras. Farmacogn., v.17, n.2, p.231-235, 2007.

BALANDRIN, M.F.; KINGHORN, A.D.; SMOLENSKI, S.J.; DOBBERSTEIN, R.H. Reverse-phase High-Pressure Liquid Chromatography of some tryptamine derivatives. J. Chromatogr., v.157, sep., p.365-370, 1978.

BODET, C.; LA, V.D.; EPIFANO, F.; GRENIER, D. Naringenin has anti-inflammatory properties in macrophage and ex vivo human whole-blood models. J. Periodontal. Res., v.43, n.4, p.400-407, 2008.

BRASILEIRO, B.G.; PIZZIOLO, V.R.; RASLAN, D.S.; JAMAL, C.M.; SILVEIRA, D. Antimicrobial and cytotoxic activities screening of some Brazilian medicinal plants used in Governador Valadares district. Rev. Bras. Cienc. Farm., v.42, n.2, p.195-202, 2006.

BURKART, A. Leguminosas - Mimosoideas. Flora Ilustrada Catarinense. Itajaí: P. Raulino Reitz, v.1, p.17-48, 1979.

CARVALHO, J.L.S.; CUNICO, M.M.; DIAS, J.F.G.; MIGUEL, M.D.; MIGUEL, O. G. Term-stability of extractive processes from Nasturtium officinale R. Br., brassicaceae for Soxhlet modified system. Quim. Nova, v. 32, n.4, p.1031-1035, 2009
CHANWITHEESUK, A.; TEERAWUTGULRAG, A.; RAKARIYATHAM, N. A. Screening of antioxidant activity and antioxidant compounds of some edible plants of Thailand. Food Chem., v. 92, n.3, p.491-497, 2005.

CHHABRA, S.C.; UISO, F.C. A survey of medicine plants of Eastern Tanzania for alkaloids, flavonoids, saponins and tannins. Fitoterapia, v.4, n.61, p.307-316, 1990.

CHOI, J.S.; PARK, K.Y.; MOON, S.H.; RHEE, S.H.; YOUG, H.S. Antimutagenic effects of plant flavonoids in the Salmonella assay system. Arch. Pharm. Res., v.17, n.2, p.71-75, 1994

CHURMS, S.C.; STEPHEN, A.M. Acid hydrolysis of the polysaccharide gum from Acacia podalyriaefolia: molecular-weight distribution studies. Carbohyd. Res., v.15, n.1, p.11-19, 1970 .

DAWN-LINSLEY, M.; EKINCI, F.J.; ORTIZ, D.; Rogers, E.; SHEA, T.B. Monitoring thiobarbituric acid-reactive substances (TBARs) as an assay for oxidative damage in neuronal cultures and central nervous system. J. Neurosci. Meth., v.141, n.2, p.219-222, 2005.

GNU OPERATION SYSTEM. R Project for statistical computing. Available at: http://www.r-project.org $>$ Accessed on: 12 mar. 2010.

HAGOS, M.; SAMUELSSON, G. Quantitative determination of Quracol A, B and (+)-fisetinidol in bark and gum of Acacia tortilis. Acta Pharm. Suec., v.25, n.6, p.321-324, 1988.

KAMBIZI, L.; AFOLAYAN, A.J. An ethnobotanical study of plants for the treatment of sexually transmitted disease (njovera) in Guruve District, Zimbabwe. J. Ethnopharmacol., v.77, n.1, p.5-9, 2001.

KERBER, V.A.; SILVA, G.A.A.B. Flavonóides da Acacia longifolia (Andr.) Willd. - Leguminosae-Mimosoideae. Rev. Bras. Farm., v.74, n.1, p16-18, 1993.

LEE, M.H.; YOON, S.K.; MOON, J.O.K. The flavonoid naringenin inhibits dimethylnitrosamine - induced liver damage in rats. Biol. Pharm. Bull., v.27, n.1, p.72-76, 2004.

MABRY, T.J.; MARKHAN, K.R.; THOMAS, M.B. The Systematic identification offlavonoids. New York: SpringerVerlag, 1970. p.35-279. 
MEERA, B.; CHANDER, J.; KALIDHAR, S. B. A review on the chemistry and bioactivity of the Acacia spp. J. Med. Aromatic Plant Sci., v.27, p.51-90, 2005.

MORAIS, S.M.; CATUNDA-JUNIOR, F.E.A.; SILVA, A.R.A.; MARTINS-NETO, J.S.; RONDINA, D.; CARDOSO, J.H.L. Antioxidant activity of essential oils from Northeastern Brazilian Croton species. Quím. Nova., v.29, n.5, p.907910, 2006.

MORIMURA, K. I.; GATAYAMA, A.; TSUKIMATA, R.; MATSUNAMI, K.; OTSUKA, H.; HIRATA, E.; SHINZATO, T.; ARAMOTO, M.; TAKEDA, Y. 5-O-Glucosyldihydroflavones from the flowers of Helicia cochinchinensis. Phytochemistry, v.67, n.24, p.2681-2685, 2006.

NABI, A.B.D.; REISINGER, E.C.; REINTHALER, F.F.; STILL, F.; EIBEL, U.; KREJS, G.J. Antimicrobial activity of Acacia nilotica (L) Willd ex Del var. nilotica (Mimosaceae). J. Ethnopharmacol., v.37, n.1, p.77-79, 1992.

NAHMIAS, Y.; GOLDWASSER, J.; CASALI, M.; POLL, D.V.; WAKITA, T.; CHUNG, R. T.; YARMUSH, M. L. Apolipoprotein $\beta$-dependent hepatitis $\mathrm{C}$ virus secretion is inhibited by the grapefruit flavonoid naringenin. Hepatology, v.47, n.5, p.1437-1445, 2008.

NATIONAL COMMITTEE FOR CLINICAL LABORATORY STANDARDS. Methods for dilution antimicrobial susceptibility tests for bacteria that grow aerobically. 4.ed. Wayne: National Committee for Clinical Laboratory Standards, 1997. Approved Standard, M7-A4.

OGUNDAINI, A.; FARAH, M.; PERERA, P.; SAMUELSSON, G.; BOHLIN, L. Isolation of two new antiinflammatory biflavanoids from Sarcophyte piriei. J. Nat. Prod., v.59, n. 6, p. 587-590, 1996.

PAREDES, A.; ALZURU, M.; MENDEZ, J.; ORTEGA, M.R. 2003. Anti-Sindbis activity of flavanones hesperetin and naringenin. Biol. Pharm. Bull., v.26, n.11, p.108-109, 2003.

RENUGADEVI, J.; PRABU, M. Naringenin protects against cadmium-induced oxidative renal dysfunction in rats. Toxicology, v.256, n.4, p.128-134, 2009.
SAITO, N.; CHENG, J.; ICHIMURA, M.; YOKOI, M.; ABE, Y.; HONDA, T. Flavonoids in the acyanic flowers of Pharbitis nil. Phytochemistry, v.35, n.3, p.687-691, 1994.

SALGADO, S.C.; ANDRADE, R.R.; CRESPO, F.A.; GALICIA, J.V.; RIVERA, I.L.; MONTES, S.; MOLINA, R.V.; SOTO, S.E. Hypoglycemic, vasorelaxant and hepatoprotective effects of Cochlospermum vitifolium (Willd.) Sprengel: A potential agent for the treatment of metabolic syndrome. $J$. Ethnopharmacol., v.109, n.3, p.400-405, 2007.

SALEEM, A.; AHOTUPA, M.; PIHLAYA, K. Total phenolics concentration and antioxidant potential of extracts of medicinal plants of Pakistan. Z. Naturforsch., v.56, n.11-12, p.973-978, 2001.

SAPONARA, S.; TESTAI, L.; LOZZI, D.; MARTINOTTI, E.; MARTELLI, A.; CHERICONI, S.; SGARAGLI, G.; FUSA, F.; CALDERONE, V. (+/-) Naringenin as large conductance $\mathrm{Ca}^{+2}$ activated $\mathrm{K}^{+}\left(\mathrm{BK}_{\mathrm{ca}}\right)$ channel opener in vascular smooth muscle cells. Br. J. Pharmacol., v.149, n.8, p.1013-1021, 2006.

SEKINE, T.; FUKASAWA, N.; IKEGAMI, F.; SAITO, K.; FUJII, Y.; MURAKOSHI, I. Structure and synthesis of a new monoterpenoidal carboxiamide from the seeds of the Thai medicinal plant Acacia concinna. Chem. Pharm. Bull., v.45, n.1, p.148-151, 1997.

WHITE, E.P. Alkaloids of the Leguminosae XXVI: examination of further legumes, mainly Lupinus and Acacia species for alkaloids. New Zeal. J. Sci. Technol., v.25, n.3, p.93-162, 1943

WU, J.H.; TUNG, Y.T.; WANG, S.Y.; SHYUR, L.F.; KUO, Y.H; CHANG, S.T. Phenolic antioxidants from the heartwood of Acacia confusa. J. Agric. Food Chem., v.53, n.15, p.59175921, 2005.

ZAPESOCHNAYA, G.G.; KURKIN, V.A.; BRASLAVSKII, V.B.; FILATOVA, N.V. Phenolic compounds of Salix acutifolia bark. Chem. Nat. Compd., v.38, n.4, p.314-318, 2002.

Received for publication on $28^{\text {th }}$ July 2009. Accepted for publication on $13^{\text {th }}$ April 2010. 